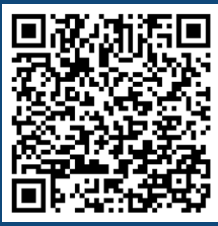

Keywords:

Urban forest sustainability

Urban landscape

Forest management

Received 22/10/2019

Accepted 04/03/2020

Correspondence: elianacleite@gmail.com
Fabricio Macedo Galvani ${ }^{\text {la }}$, Thais Graciano-Silva ${ }^{\text {lb }}$ Eliana Cardoso-Leite ${ }^{\text {lc+ }}$

\section{IS BIOTIC INTEGRITY OF URBAN FORESTS REMANTS RELATED WITH THEIR SIZE AND SHAPE?}

GALVANI, F. M.; GRACIANO-SILVA, T.; CARDOSO-LEITE, E. Is biotic integrity of urban forests remants related with their size and shape? CERNE, v. 26, n. I, p.9-17, 2020.

\section{HIGHLIGHTS}

The size of urban forests has a direct relationship with the biotic integrity of the ecosystem.

There is a relationship between the shape of urban forests and their biotic integrity but it is weak.

In general, small urban forests exhibit low integrity and large urban forests exhibit high integrity.

Besides size and shape, other factors seem to affect the biotic integrity of urban forests, such as the history of disturbance and conservationist management.

\section{ABSTRACT}

The Brazilian Atlantic Forest (BAF) is one of the biodiversity hotspots, but in the last decades, it has been fragmented due to agricultural and urban-industrial expansion, which has a strong impact on forest fragments. The goal of this study was to analyze the Biotic Integrity Index (BII) in fragments of BAF in two medium-sized cities in Southeastern Brazil and to analyze the relation between BII and landscape metrics (size and shape). The method (BII) has eleven indicators (litter, grass, dead trees, exotic species, vines, gaps, epiphytes, orchids, palms, later species in canopy and understory). The survey was carried out in nine forest fragments in Ribeirão Preto (SP) and 23 in Sorocaba (SP), with a size variation between 0.33 and 185 ha, all of them in urban influence. The relation between BII and landscape metrics were analyzed by the Pearson regression. BII value was registered from 28.7 to 40.0 to Ribeirão Preto and from 22.34 to 35.34 to Sorocaba. Pearson regression was strong between IBB and the size for both cities $(p=0.742$ to Ribeirão Preto, and $p=0.679$ to Sorocaba). Pearson regression between IBB and shape was medium to Ribeirão Preto $(p=0.47)$ and weak to Sorocaba $(0.1838)$. The results showed that there is a strong relation between BII and size, and less correlation between BII and shape. However, only size is not able to explain all variation in integrity, suggesting that other factors such as disturbance history and conservation management should have greater influence than the fragment size. 


\section{INTRODUCTION}

The Brazilian Atlantic Forest is one of the biodiversity hotspots in the world due to its great biodiversity, endemism and threat level (Myers et al., 2000). In Brazil this forest was significantly modified and fragmented, thus, $\mathbf{8 8 . 3 \%}$ of the original Brazilian Atlantic Forest was lost and only I I.7\% of the original vegetation remains (Ribeiro et al., 2009). Currently, it is distributed in 245, 173 forest fragments, the largest of it is located in the Serra do Mar, mainly along the coastal mountains of São PauloState, but the small fragments ( $<50 \mathrm{ha})$ are currently the most of them (Ribeiro et al., 2009).

Changing in land use transforms areas with native vegetation into urban or agricultural areas and it destroys forests and other natural ecosystems, and it modifies their size, shape and, isolation degree in the landscape (Ferraz et al., 20l4; Mello et al., 2016). As in the last decades human society has been concentrated in the cities, this has increased the pressure of destruction of natural ecosystems to occupy the space with urban expansion. Nowadays the urban population is $30 \%$ larger than the population of 50 years ago and the cities areas are gaining 67 million people a year (Picket et al., 20I I).

The development of urbanization fragments natural ecosystems causes species homogenization (Aliberti and Marzuff, 2004) and increases the frequency of exotic species (Heckmann et al., 2008) due to the edge effects (Murcia, 1995; Pohlman et al., 2007; Haddad et al., 20I5) and habitat degradation (Haddad et al., 2015), despite the importance of these forests in the urban matrix. Liu et al. (2018) in a recent review about this issue concluded that fragmentation can affect the ecosystem function modifying the community composition directly, as well as indirectly by changing environmental conditions in habitat patches.

Natural ecosystems are important because they provide ecosystem services for human societies. They not only provide services such as food, fiber, wood, pollinators, climate and, water regulation (avoiding heating zones in cities, avoiding floods and landslides), but also cultural services, such as recreation and aesthetics (Millenium Ecosystem, 2005; Pascual et al., 2017; Peterson et al., 2018). So, urban forests have been recognized as essential components of sustainable cities (Steenberg et al., 2015).

As an attempt to evaluate the biotic integrity of forest fragments in Paraná State, Medeiros and Torezan (20I3) proposed a Biotic Integrity Index (BII) based on studies of Rapid Ecological Assessment (Sayer et al., 2000). This index (BII) is composed of a simple set, easily measurable variables that, when analyzed as a whole, can reveal much about the state of biotic integrity of the forest. As the original study (Medeiros and Torezan, 2013) was carried out in forest fragments inserted in a rural matrix, Graciano-Silva et al. (2018) adapted the Bll method for forest fragments in an urban matrix, that is, in urban forests.

The urbanization is destroying the natural ecosystem, devastating biodiversity and ecosystem services (WU, 2010). Changes in the structural composition of urban forests can cause changes in certain ecosystem functions (LIU et al., 20l8) that maximize human wellbeing in cities (Dobbs et al., 20I I). Therefore, knowledge about the ecological dynamics and biotic integrity of forest fragments inserted in an urban matrix is essential to guide public policies and support decision-makers in the planning and management of territories.

In this way, the following questions are very relevant and they guided the present study: - "Do urban forests have any biotic integrity that can guarantee their survival over time?" - "Is the biotic integrity of urban forests related to their size and shape?"

This study aimed to analyze the Biotic Integrity in Atlantic Forest fragments inserted in an urban matrix, in medium-sized cities in the Southeast of Brazil (Ribeirão Preto/SP and Sorocaba/SP) and to analyze the relationship between biotic integrity and landscape metrics (size and shape of the fragments).

\section{MATERIALS AND METHODS}

\section{The study area}

This study was carried out in the municipalities of Ribeirão Preto and Sorocaba (Figures I and 2), two middle-sized cities located in the Southeast of Brazil, in São Paulo State. The original vegetation in the region is Atlantic Rain Forest. Another natural vegetation in this region is the Savanna, but the present study focused specifically on the forest fragments (Figures I and 2).

It was selected nine forest fragments in Ribeirão Preto (Figure I) in the municipality area where they have some relation with the urban area. The choice of these fragments was based on a previous study (KonthetkoffHenriques, 2003). The size of the analyzed areas varied from I.3 to I85 ha. Therefore, the survey included two protected areas (Porto Ferreira and Vassununga State Park) as the "reference", because these are wellpreserved forests. Both state parks are located $100 \mathrm{~km}$ from Ribeirão Preto (Vieira et al, 1989).

It was selected twenty-three forest fragments in Sorocaba (Figure 2) in the municipality area, wherethey have some relation with the urban area, and the choice 


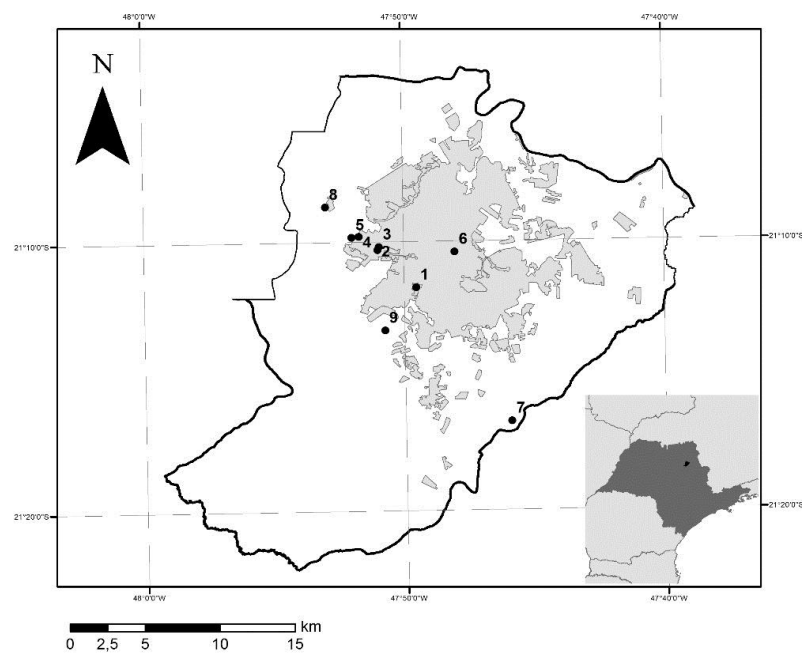

FIGURE I Sample units (forest fragments) analyzed in Ribeirão Preto/SP, Brazil. The area names are shown in Table 2.

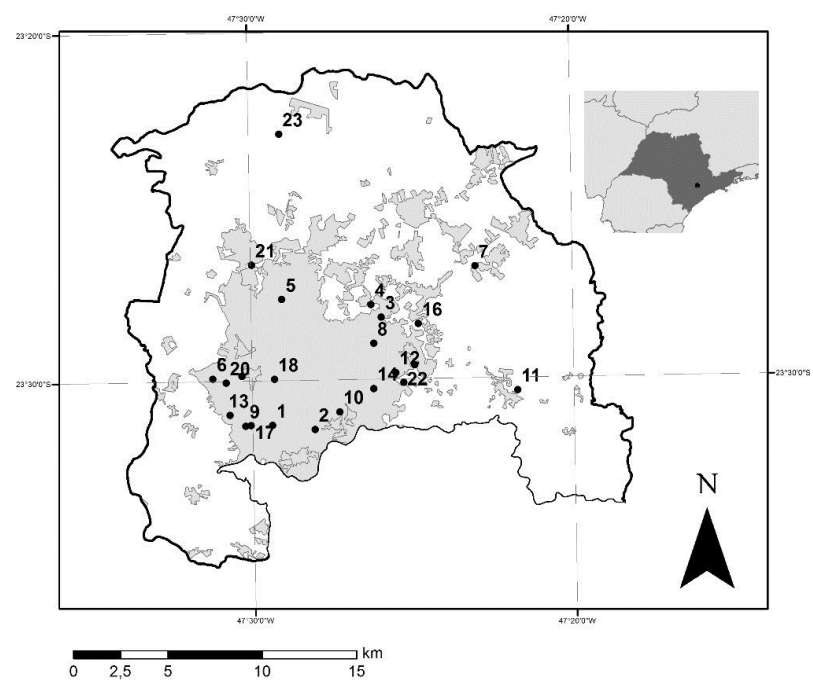

FIGURE 2 Sample units (forest fragments) analyzed in Sorocaba/ SP, Brazil. The area names are shown in Table 2.

of these fragments was based on previous studies (Mello et al., 2016, Mota et al., 2016). The size of the analyzed areas varied from 0.33 to $3 \mathrm{I}$ ha. Therefore the survey included one protected area (Ipanema National Forest) as the "reference" because this is a well-preserved forest. This National Forest is located $10 \mathrm{~km}$ from Sorocaba (Albuquerque and Rodrigues, 2000).

\section{Data collecting}

\section{Biotic Integrity Index}

It was calculated the Biotic Integrity Index (BII), proposed by Medeiros and Torezan (2013) and adapted by Graciano-Silva et al., (20I8), for each area. It was used 3 plots of $10 \times 10 \mathrm{~m}$ (or 100 meters square), inside each fragment.
BII contains eleven indicators (or ecological variables) and the selection of these indicators was based on literature review, most previous studies (Medeiros and Torezan, 20I3; Gregorini, 20I5; Graciano-Silva, 2016), with adaptations for species (Indicators I0, II) using previous studies as Konthetkoff-Henriques (2003) to Ribeirão Preto, and Albuquerque and Rodrigues (2000) and Coelho et al. (2016) to Sorocaba. Table I shows these indicators and the possible value variation.

Each indicator received a score ranging from $I$ to 5 (Table I). The Bll values were obtained through the sum of each of the indicators, with the maximum value of integrity of 55 representing a fragment with excellent biotic integrity and a minimum value of $\mathrm{I} \mathrm{I}$, representing a highly degraded fragment (very low integrity). The score obtained and the degree of integrity followed the proposal of Medeiros and Torezan (2013) where values from II to 19.9 are considered "Very Low Integrity", from 20 to 29.9 "Low Integrity", 30 to 39.9 "Medium Integrity", from 40 to 49.9 "Good (or High) Integrity" and, from 50 to 55 "Excellent (Very High) Integrity".

\section{Landscape metrics}

It was analyzed the size and shape of the forest fragments studied. These metrics were chosen based on ecological concepts. The first one was the Island Biogeography (Macarthur and Wilson, 1967) in which large areas should have greater biodiversity (Metzger, 1999; Mello et al., 2016). Then, the edge effect, in which the influence of the adjacent landscape is large and it depends on the shape of the patches (Murcia, 1995; Pohlman et al., 2007; Haddad et al., 20I5).

The landscape metrics analyses were performed through image capture using the SAS Planet software. The source of the images is from Bing Maps Satellites, for the delimitation of the polygons and the land use mapping it was used ArcGis 9.2 software. Fragstats Software was used to calculate the metric variables. The analysis of the variables related to the landscape proposed for the present study is described below.

The size of the fragments was calculated from the drawing of the polygon occupied by the fragment, using the Esri ArcMap 10.2.2 Program, and the calculation was done using the Calculate Geometry Tool with the shapefiles open for editing of the same program.

The shape of forest patches is determined by the size and the perimeter of the area. A circular shape is the one that minimizes the perimeter/area ratio and generates edges with the same length from the patch center. The shape is a spatial attribute that is difficult 
TABLE I Indicators and degree of biotic integrity (Adapted from GRACIANO-SILVA, 20 I6). I - Copaifera langsdorfii, Aspidosperma spp, Cariniana spp for both as areas, and Cedrela fissilis only for Sorocaba, 2 - Species of the genus Trichilia and species of families Myrtaceae and Rubiaceae.

\begin{tabular}{|c|c|c|c|c|c|}
\hline \multirow[t]{2}{*}{ INDICATOR } & \multicolumn{5}{|c|}{ INTEGRITY DEGREE } \\
\hline & I & 2 & 3 & 4 & 5 \\
\hline I-Litter cover (\%) & $0-20 \%$ & $20 \%-50 \%$ & $50 \%-80 \%$ & $100 \%$ - deep less $10 \mathrm{~cm}$ & $100 \%$ - deeep more $10 \mathrm{~cm}$ \\
\hline 2-Standing dead trees (number of individuals) & 4 or more & 3 & 2 & l & 0 \\
\hline 3-Exotic grass cover $(\%)$ & $>70 \%$ & $51-70 \%$ & $21-50 \%$ & $5-20 \%$ & Absent \\
\hline 4-Wood lianas and vine tangles & $\begin{array}{c}\text { Just vine tangles ( } 3 \\
\text { or more) }\end{array}$ & Just vine tangles (2) & $\begin{array}{c}\text { Just vine tangles } \\
\text { (I) }\end{array}$ & Wood and vine tangles & Just wood \\
\hline 5-Gaps in canopy (\%) & More than $50 \%$ & From 25 to $50 \%$ & From II to 25 & Present until $10 \%$ & Absent \\
\hline 6-Vascular epiphytes (number of individuals) & Absent & $\mathrm{I}$ & 2 & 3 & 4 or more \\
\hline 7- Orchids (number of individuals) & Absent & I & 2 & 3 & 4 or more \\
\hline 8-Palms (number of individuals) & Absent & Only youngs & I adult + youngs & 2 adults & 3 adults or more \\
\hline 9-Exotics wood species (number of individuals) & 4 or more & 3 & 2 & I & Absent \\
\hline I0-Later species in canopy (number of individuals) I" & Absent & I & 2 & 3 & 4 or more \\
\hline II-Later species in understory (number of species) 2 & Absent & I & 2 & 3 & 4 or more \\
\hline
\end{tabular}

to be undertaken in a metric analysis because there are many possible ways to do it. So, for the evaluation, it is necessary to adopt an indexed constant (c), which takes different values to different formats, that allows assimilation from the form to the standard geometric shapes (circle, ellipse, square, etc.). A perfect circle has a shape value of zero, and shape values $\geq 6$ are heuristically considered irregular. The shape was calculated by the analysis system program (McGarigalet al., 20I5; Graciano-Silva, 2016). The shape of the fragments was calculated using Equation I, also used by Graciano-Silva (2016). where: A - Size of study area; P - Perimeter of study area; $\mathrm{c}$ - Correction factor

$$
\text { Shape }=A / \sqrt{P} / \mathrm{c}
$$

\section{Data analysis}

In order to analyze the relationship between the Bll and the fragment size, Pearson linear regression was calculated (Zar, 20I0; McDonald, 20I4) using the logarithm of the areas in hectares of the fragments. Using the logarithm for the areas aims to analyze how the relationship is established, once the oscillation of the values for the areas is much greater than the values of BII, especially data from Ribeirão Preto where the areas vary from 0.52 to 188.25 , compared to values between II and 55 to BlI.The Pearson linear regression (Zar, 2010; Mcdonald, 2014) was also used to analyze the relation between BII and the fragment shape.

The organization of the data was done with the elaboration of tables through Microsoft Excel software, the elaboration of the correlation graphs and the values of the Pearson regression were obtained through the language R (Zar, 20I0; McDonald, 20I4).

\section{RESULTS}

The results showed that the size of the areas in Sorocaba ranged from 0.32 to $3 \mathrm{I}$ ha (Table 2) and in Ribeirão it varied from I.3 to I85 ha (Table 2). It means there was a greater variation in the size of the area in Ribeirão Preto.
The shape value can vary between 0 (circular) and 6 (irregular shape). For the most of fragments from Sorocaba were recorded shape values between I and 2 (Table 2), and only one area (Ouro Fino Park) presented a larger value, which is a more irregular shape. For Ribeirão Preto (Table 2) the shape values varied from 1.91 to 4.22 , they presented more irregular forms.

The values of biotic integrity recorded an IBB ranging from 22.34 to 33.34 for fragments of Sorocaba and from 28.7 to $\mathbf{4 0 . 0}$ for fragments of Ribeirão Preto (Table 2). The results of the regression between area size and BII and between shape and BII are shown in Figure 3 , where it is possible to see a stronger positive relationship between size and BII, and a weaker positive relationship between shape and BII.

\section{DISCUSSION}

About integrity Sorocaba (Table 2) presented a large part of the fragments $(65.3 \%)$ with low BII and a small part of the areas (34.7\%) with medium BII, whereas Ribeirão Preto (Table 2) presented a large part of the fragments (55.5\%) BII medium and a small part (22.2\%) BII low, as well as another small part (22.2\%) BII high. That is, there are more fragments with low integrity in Sorocaba and a large part shows medium or high integrity in Ribeirão Preto.

Comparing these results to those obtained by Medeiros and Torezan (2013) they can be observed that the authors registered very high Bll only for the reference area, high for $30 \%$ of the areas, medium Bll for $50 \%$ of the areas and, low for only $20 \%$ of them. Therefore, we can say that the data from Ribeirão Preto are similar from those recorded by Medeiros and Torezan (20I3) for forest fragments in the region of Londrina (PR). It must be considered that the study of Medeiros and Torezan (2013) was carried out in forest fragments inserted in a rural matrix and the present study in 
an urban matrix that could have affected the fragments even more, decreasing their integrity.

On the other hand, Graciano-Silva et al. (2018) considered as sustainable areas (forest ecosystems with long-term capacity) those with high or very high BII (over 40 ) or those which registered a minimum of $60 \%$ of the maximum possible value of the Bll. Considering this percentage $(60 \%$ out of 55 , maximum value possible to BII), we could say that in Sorocaba 4, out of 23 analyzed areas, present some sustainability and in Ribeirão Preto 7 , out of 9 analyzed areas, present some sustainability.

The Pearson regression between the size and $\mathrm{BI}$ data was positive (Figure 3A, 3B) and strong for both municipalities ( 0.742 for Ribeirão Preto and 0.679 for Sorocaba). It can be observed (Table 2 ) that very small areas (up to 2 or 2.5 ha) presented low integrity, just large areas (above $185 \mathrm{ha}$ ) presented high integrity. However, relatively small areas (Fabio Barreto - 21.8 ha) presented high integrity (Table 2) or relatively large areas (Petrochemical Terminal - 76.5 ha) showed medium integrity (Table 2) indicating that there is a relation between the size of the forest fragment and biotic integrity, but that only size is not able to explain all variation in BII.
The area "Fabio Barreto" (Figure I) is a relatively small forest and its surroundings are completely urbanized, but it has been conserved as a "Municipal Forest" and it was inserted in an Environmental Preservation Area (Brasil, 2000) or Protected Landscape (IUCN, 1994) for the last 30 years. Thus, this conservationist management must have helped significantly in the preservation of the fragment, preventing common stressors in urban fragments such as the opening of clearings for the collection of wood, fire, waste disposal, drainage, among others. In this way, a fragment that presents a balanced forest structure and dynamics, between its strata, canopy and, the different groups of species (Connell, 1978; Ordóñez; Duinker, 20I2), even with an occupancy of strongly anthropized environment, can keep high integrity.

The area "Petrochemical Terminal" (Figure I) is relatively large (76.5 ha) and did not record high integrity. Signs of fire occurrence in the recent past have been observed in the area and this fact may justify the high rate of grasses and lianas (indicators 3, 4 (Table I) at the edges of this fragment (Pohlman et al., 2007; Silva et al., 2017). In this area, there were few late understory and canopy species (Indicators 10 and I I, Table I) indicating

TABLE 2 IBB results for areas analyzed in Ribeirão Preto and Sorocaba,SP, Brazil. * representsthe reference areas used for comparison. The location of the areas is shownin Figure I (Ribeirão Preto) and Figure 2 (Sorocaba).

\begin{tabular}{|c|c|c|c|c|c|}
\hline Areas- Ribeirão Preto & Size- ha & Shape & $\mathrm{BII}$ & Integrity & $\% \mathrm{BII}$ \\
\hline I - Santa Tereza Hospital & 1.3 & 2.15 & 28.7 & Low & 52.1 \\
\hline 2- Coffe Museum - fragment I & 2.3 & 4.37 & 36.3 & Medium & 66.1 \\
\hline 3- Caffe- fragment 2 & 2.7 & 3.49 & 29.3 & Low & 53.3 \\
\hline 4- USP -São Paulo University - didatic center & 3.5 & 3.76 & 34.7 & Medium & 63.0 \\
\hline 5- USP- São Paulo University -- west fragment & 4.8 & 3.26 & 34.0 & Medium & 61.8 \\
\hline 6- Fábio Barreto & 21.8 & 3.37 & 40.3 & Hight & 73.3 \\
\hline 7- Santa Maria & 47.2 & 4.22 & 38.3 & Medium & 69.7 \\
\hline 8- Petrochemical Terminal & 76.5 & 1.91 & 36.0 & Medium & 65.5 \\
\hline 9- Ribeirão Preto Ecological Station & 185.0 & 4.12 & 40.0 & Hight & 72.7 \\
\hline * Vassununga State Park & 331.2 & - & 40.3 & Hight & 73.3 \\
\hline *Porto Ferreira State Park & 611.6 & - & 40.0 & Hight & 72.7 \\
\hline Areas- Sorocaba & Size- ha & Shape & Bll & Integrity & $\% \mathrm{BII}$ \\
\hline I - Agua Vermelha Park & 0.32 & 1.79 & 23.67 & Low & 43.0 \\
\hline 2- Carlos Alberto Souza Park & 0.48 & 1.4 & 25.34 & Low & 46.1 \\
\hline 3-Yves Ota Park & 1.00 & 2.35 & 26 & Low & 47.3 \\
\hline 4-Jardim Botânico Park & 1.3 & 1.54 & 29.33 & Low & 53.3 \\
\hline 5-Juraci A. Boaro Park & 1.44 & 1.55 & 23.67 & Low & 43.1 \\
\hline 6-Miguel Gregório Park & 1.55 & 1.6 & 26 & Low & 47.3 \\
\hline 7-Raul Bittencourt Park & 2.38 & 1.9 & 22.34 & Low & 40.6 \\
\hline 8-Armando Pannunzio Park & 2.46 & 2.4 & 26.67 & Low & 48.5 \\
\hline 9- Villa dos Inglezes & 2.49 & 1.38 & 29 & Low & 52.7 \\
\hline I0-Biquinha Park & 2.63 & 2.14 & 31 & Medium & 56.4 \\
\hline I I-Brigadeiro Tobias Park & 2.99 & 2.18 & 30.66 & Medium & 55.7 \\
\hline 12-Jardim Gonçalves & 3.78 & I & 29.67 & Low & 53.9 \\
\hline | 3-Piazza di Roma || & 4.72 & 2.3 & 28.67 & Low & 52.1 \\
\hline I4-Quinzinho de Barros Zoo & 5.06 & 1.54 & 32.67 & Medium & 59.4 \\
\hline I5-Braulio Guedes Park & 6.23 & 2.4 & 35.34 & Medium & 64.2 \\
\hline 16-Chico Mendes Park & 6.26 & 2 & 35.34 & Medium & 64.2 \\
\hline |7-Piazza de Roma I & 6.67 & 2.2 & 28.67 & Low & 52.1 \\
\hline 18-Jardim Simus & 7.52 & 2 & 29.34 & Low & 53.3 \\
\hline 19-Ouro Fino Park & 8.03 & 4.43 & 30.34 & Medium & 55.1 \\
\hline 20-Wanel Ville & 9.03 & 2 & 28 & Low & 50.9 \\
\hline 2I-Pedro P. Almeida Park & 12.25 & 2.1 & 29 & Low & 52.7 \\
\hline 22-Três Meninos Park & 19.16 & 2 & 33.34 & Medium & 60.6 \\
\hline 23-Corredores da Biodiversidade Natural Municipal Park & 31.0 & 2 & 33.34 & Medium & 60.6 \\
\hline *Ipanema National Forest & 5000 & - & 40.0 & Hight & 72.7 \\
\hline
\end{tabular}


A

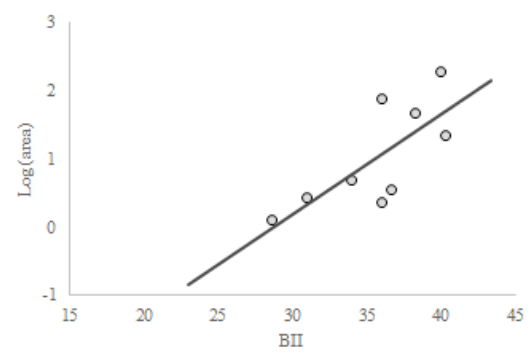

C

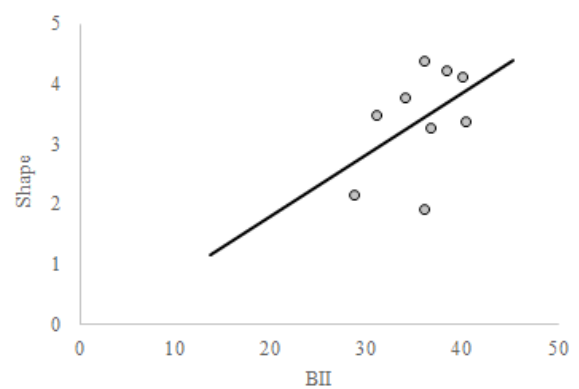

B

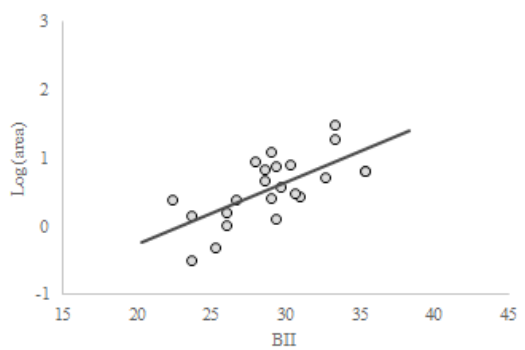

D

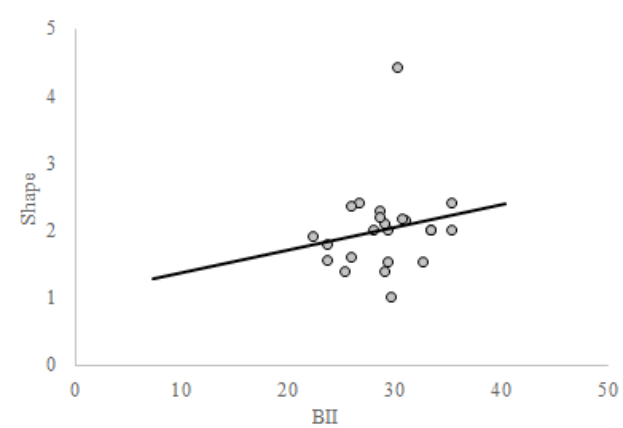

FIGURE 3 Pearson regression between BII and area size and between BII and shape. A) BII and area size to Ribeirão Preto ( $p=$ $0,742)$; B) BII and size area to Sorocaba ( $=0,679)$; $C)$ BII and shape to Ribeirão Preto $(p=0,46 \mid 4)$; D) BII and shape to Sorocaba $(p=0,1838)$.

that the fire must have impaired the regeneration of late canopy species in both the canopy and understory strata. The fire must have provided an excess of disturbance (Connel, 1987; Amenteras et al., 2013) and promoted the establishment of pioneer species.

These results show that sometimes the history of disturbances in the area influences negatively and more strongly than its size (Petrochemical Terminal area). On the other hand, it also shows that when conservationist management (Fabio Barreto area) avoids the possible anthropic disturbances it can positively influence the BII. So areas with reduced size can present good biotic integrity. Steenberg et al. (2019) draw attention to the importance of municipal management for the conservation and maintenance of urban forests.

Pearson regression between shape and BII (Fig. 3C, 3D) was positive for both municipalities but weak for Sorocaba and medium for Ribeirão Preto, contrary to expectations. Following previous studies (Ferraz et al. 2014; Mello et al., 2016) it was expected a strong relation because circular drawing should have a core area, where ecosystem structure and function should have been kept. The results showed a medium relation for Ribeirão Preto, where the areas varied in size and in shape. On the other hand, for Sorocaba, despite of the circular shape of the most fragments, the size of them was tiny, so the edge effect (Harper et al., 2005; Pohlman et al., 2007; Haddad et al., 20I5) must have been strong for all fragments, regardless of their shape.

The results show that the exclusive effect of the shape on the biotic integrity is small or medium, but they seem to indicate that the shape and size of the area influence the maintenance of ecological processes when analyzed together (Muchailh, 20I0; Mello et al. 20I6). In fact, what influences or not the biotic integrity is the presence of edges, known as "edge effect" (Murcia, 1995, Silva et al., 2017) which increases the occurrence of light and wind, and this reduces shading and moisture (Silva et al., 2007). Also, there is an increase of the presence of dead trees, clearings, lianas and grasses. These indicators (mainly exotic grasses and dead trees) were present basically in all the studied areas of Sorocaba (GracianoSilva et al., 2018) and most of them also in Ribeirão Preto (Galvani, 2018). Besides, the occurrence of the "vascular epiphyte" indicator and the absence of "orchids" were also registered for both municipalities, which must be related to the increase of the winds, and the decrease of the relative humidity of the air.

It is important to highlight that all areas used as "reference areas" are protected areas (Brasil, 2000; IUCN, 1994) where high Bll were recorded (Table 2). This may be related to the size of these areas, which are usually much larger compared to urban forests. As 
they are large areas, the "edge effect" tends to decrease, even if the area drawing is irregular, because all of them can maintain a core area, regardless of the edges. Yet, high integrity may also be related to conservationist management, which is actually managing to avoid the occurrence of anthropic disturbances, thus maintaining them with high integrity.

\section{CONCLUSIONS}

The results allow concluding that the size of urban forests has a linear relationship with the biotic integrity of the ecosystem and that the shape of the fragment influences the integrity but with less intensity.

The results showed that very small urban forests (between 2 and $2.5 \mathrm{ha}$ ) generally exhibit low integrity and large urban forests (over 180 ha) exhibit high integrity. The results also indicated that there may be a minimum size for urban forests (around 20 ha) from which high integrity can be already expected, and this integrity can guarantee their survival over time. However, this will also depend on other factors, mainly historical disturbing elements and conservationist management.

Although the size and integrity are directly related, the results showed that factors such as disturbances, often caused by urbanization, influence negatively and more strongly than the size of the area itself. On the other hand, conservation management can help to maintain or enhance the integrity of urban forests, even if they are relatively small. This data is certainly relevant and it could be used in territorial planning and management by decision-makers in public policies elaboration.

\section{REFERENCES}

ALBERTI, M.; MARZLUFF, J. M. Ecological resilience in urban ecosystems: Linking urban patterns to human and ecological functions. Urban Ecosystems, v. 7, p. 24I-265, 2004.

ALBUQUERQUE, G. B.; RODRIGUES, R. R. A vegetação do Morro de Araçoiaba, Floresta Nacional de Ipanema, Iperó (SP). Scientia Forestalis, v. 58, p.I45-I59, 2000.

ARMENTERAS, D. G.; GONZÁLES, T. M. R. Forest fragmentation and edge influence on fire occurrence and intensity under different management types in Amazon forests. Biological Conservation, v. 159, p.73-79, 2013.

BRASIL. Lei $n^{\circ} 9.985$, de 18 de jul. de 2000. Ministério do Meio Ambiente. Institui o Sistema Nacional de Unidades de Conservação da Natureza e dá outras providências. Diário Oficial da República Federativa do Brasil Brasília, 23 de out. de 2002.

COELHO, S.; CARDOSO-LEITE, E.; CASTELLO, A. C. D. Composição Florística e Caracterização Sucessional como subsídio para conservação e manejo do PNMCBIO, Sorocaba, SP. Ciência Florestal, v. 26, n. I, p. 33I-344, 2016.
CONNELL, J. H. Diversity in Tropical Rain Forests and Coral Reefs. Science, New Series, v. 199, n. 4335, p.1302|310, 1987.

DOBBS, C.; ESCOBEDO, F. J.; ZIPPERER, W. C. A framework for developing urban forest ecosystem services and goods indicators. Landscape and Urban Planning, v. 99, p. 196-206, 2011.

FERRAZ S. B. F; FERRAZ, K. M. P. M. B.; CASSIANO, C. C.; BRANCALION, P. H. S.; DA LUZ D. T. A.; AZEVEDO, T. N.; TAMBOSI, L. R.; METZGER, J. P. How good are tropical forest patches for ecosystem services provisioning? Landscape Ecology, v. 29, p. 187-200, 2014.

GALVANI, F. M. Integridade biótica de fragmentos florestais em matriz urbana. 2018. 77 p. Dissertação de mestrado. Universidade Federal de São Carlos, Sorocaba.

GRACIANO-SILVA, T. Análise e estabelecimento do índice de integridade biótica para florestas urbanas. 2016. 86 p. Dissertação de mestrado. Universidade Federal de São Carlos, Sorocaba.

GRACIANO-SILVA, T.; MELLO, K.; CARDOSO-LEITE, E. Adaptação e eficiência de um índice de integridade biótica para análise da sustentabilidade em florestas urbanas. Gaia Scientia, v. 12, n. 2, p. 60-75, 2018.

GREGORINI, R. A. Análise de áreas para criação de unidades de conservação no município de Boituva (SP). 2016.95 p. Dissertação de mestrado. Universidade Federal de São Carlos, Sorocaba.

HADDAD, N. M.; BRUDVIG, L.A.; CLOBERT, J.; DAVIES, K. F.; GONZALEZ, A.; HOLT, R. D.; LOVEJOY, T. E.; SEXTON, J. O.; AUSTIN, M.P.; COLLINS, C. D.; COOK, W. M.; DAMSCHEN, E. I.; EWERS, R. M.; FOSTER, B. L.; JENKINS, C. N.; KING, A. J.; LAURANCE, W. F.; LEVEY, D. J.; MARGULES, C. R.; MELBOURNE, B. A.; NICHOLLS, A. O.; ORROCK, J. L.; SONG, D.; TOWNSHEND, J. R.Habitat fragmentation and its lasting impact on Earth's ecosystems. Science Advances, v. I, p. I-9, 20 I5.

HARPER, K. A.; MACDONALD, S. E.; BURTON, P. J.; CHEN, J.; BROSOFSKE, K. D.; SAUNDERS, S. C.; ESSEEN, P. A. Edge influence on forest structure and composition in fragmented landscapes. Conservation Biology, v. 19, n. 3, p. 768-782, 2005.

HECKMANN, K. E.; MANLEY, P. N.; SCHLESINGER, M. D. Ecological integrity of remnant montane forests along an urban gradient in the Sierra Nevada. Forest Ecology and Management, v. 255, p. 2453-2466, 2008.

IUCN - Internacional Union for Conservation of Nature, 1994. Guidelines for protected area management categories. Available at: https://www.iucn.org/content/ guidelines-protected-area-management-categories Accessed in: 20 may 2019.

KOTCHETKOFF-HENRIQUES, O. Caracterização da vegetação natural de Ribeirão Preto, SP: Bases para conservação. 2003. 270 p. Tese de doutorado. Universidade de São Paulo, Ribeirão Preto. 
LIU, J.; WILSON, M. H. U. G.; LIU, J.; WU, J.; YU, M. How does habitat fragmentation affect the biodiversity and ecosystem functioning relationship? Landscape Ecology, v. 33, p.34I-352, 2018.

MACARTHUR, R. H.; WILSON, E. O. The Theory of Island Biogeography. Princeton Landmarks in Biology, 1967. 224 p.

MACDONALD, J. H. Handbook of Biological Statistics. Sparky House Publishing, 2014. 299 p.

MCGARIGAL, K. Fragstat Help. Available at: http:umass. edu/landeco/research/fragstats/documents/fragstats. help.4.2.pdf Accessed in: 20 may 2019.

MEDEIROS, H. R.; TOREZAN, J. M. Evaluating the ecological integrity of Atlantic forest remnants by using rapid ecological assessment. Environ Monit Assess, v. 185, p. 4373-4382, 2013.

MELLO, K.; TOPPA, R. H.; CARDOSO-LEITE, E. Priority areas for forest conservation in an urban landscapeat the transition between atlantic forest and cerrado. Cerne, v. 22, n. 3, p. 277-288, 2016.

METZGER, J. P. Estrutura da Paisagem e Fragmentação: Análise Bibliográfica. Anais da Academia Brasileira de Ciências, v.7I, p. 445-462, 1999.

MILLENNIUM ECOSYSTEM ASSESSMENT Ecosystems and Human Well-being: Synthesis. World Resources Institute, 2005. 137 p.

MOTA, M. T.; CARDOSO-LEITE, E.; SOLA, F; MELLO, K. Categorização da infraestrutura verde do município Sorocaba (SP) para criação de um sistema municipal Integrando espaços livres e áreas protegidas. RBCIAMB, v.4I, p. I22-140, 2016.

MUCHAILH, M. C.; RODERJAN, C. V.; CAMPOS, C. B.; MACHADO, A. L. T.; CURCIO, G. R. Metodologia de planejamento de paisagens fragmentadas visando a formação de corredores ecológicos. Floresta, v. 40, n. I, p. I47-162, 2010.

MURCIA, C. Edge effects in fragmented forests: implications for conservation. Tree, v. 10, p. 58-62, 1995.

MYERS, N.; MITTERMEIER, R. A.; MITTERMEIER, C. G.; FONSECA, G. A. B.; KENT, J. Biodiversity hotspots for conservation priorities. Nature, v. 403, p. 853 858, 2000.

ORDÓÑEZ, C.; DUINKER, P. N. Ecological integrity in urban forests. Urban Ecosyst, v. I5, p. 863-877, 2012.
PASCUAL, U.;BALVANERA, P.; DIAZ, S.; PATAKI, G.; ROT, E.; STENSEKE, M.;WATSON, R. T.; DESSANE, E. B.; ISLAR, M.; KELEMEN, E.; MARIS, V.; QUAAS, M.; SUBRAMANIAN, S. M.; WITTMER, H.; ADLAN, A.; AHN, S.; AL-HAFEDH, Y.; AMANKWAH, E.; SAH, S. T.; BERRY, P.; BILGIN, A.; BRESLOW, S. J.; BULLOCK, C.; CÁCERES, D.; DALYHASSEN, H.; FIGUEROA, E.; GOLDEN, C. D.; GÓMEZBAGGETHUN, E.; GONZÁLEZ-JIMÉNEZ, D.; HOUDET, J.; KEUNE, H.; KUMAR, R.; MA, K.; MAY, P. H.; MEAD, A.; O'FARRELL, P.; PANDIT, R.; PENGUE, W.; PICHISMADRUGA, R.; POPA, F.; PRESTON, S.; PACHECOBALANZA, D.; SAARIKOSKI, H.; STRASSBURG, B. B.; BELT, M. V. D.; VERMA, M.; WICKSON, F; YAGI, N.Valuing Nature's contributions to people: the IPBES approach. Current Opinion in Environmental Sustainability, v. 26, n. 27, p. 7-16, 2017.

PETERSON, G. D. Z. V.; HARMACKOVA, M.; MEACHAM, C.; QUEIROZ, A.; JIMÉNEZ-ACEITUNO, J. J.; KUIPER, K.; MALMBORG, K.; SITAS, N.; BENNETT, E. M. Welcoming different perspectives in IPBES: "Nature's contributions to people" and "Ecosystem services". Ecology and Society, v. 23, n. I, 2018 .

PICKETT, S. T. A.; CADENASSO, M. L.; GROVE, J. M.; BOONE, C. G.; GROFFMAN, P. M.; IRWIN, E.; KAUSHAL, S. S.; MARSHALL, V.; MCGRATH, B. P.; NILON, C. H.; POUYAT, R. V.; SZLAVECZ, K.; TROY, A.; WARREN, P. Urban ecological systems: Scientific foundations and a decade of progress. Journal of Environmental Management, v. 92, p. 33I-362, 201 I.

POHLMAN, C. L.; TURTON, S. M.; GOOSEM, M. Edge effects of linear canopy openings on Tropical Rain Forest understory microclimate. Biotropica, v. 39, p. 62-7I, 2007.

RIBEIRO, M. C.; METZGER, J. P.; MATERSEN, A. C.; PONZONI, F. J.; HIROTA, M. M. The Brazilian Atlantic Forest: How much is left, and how is the remaining forest distributed? Implications for conservation. Biological Conservation, v. I42, p. I|4| - I I53, 2009.

SAYRE, R.; ROCA, E.; SEDAGHATKISH, G.; YOUNG, B.; KEEL, S.; ROCA, R. Nature in focus: Rapid ecological assessment. The Nature Conservancy, 2000. 185 p.

SILVA, B. G.; CASTELLO, A. C. D.; KOCH, I.; SILVA, W. R. Pathways affect vegetation structure and composition in the Atlantic Forest in southeastern Brazil. Acta Botanica Brasilica, v. 31, n. I, p. 108-119, 2017.

STEENBERG, J. W. N.; MILLWARD, A. A.; DUINKER, P. N.; NOWAK, D. J.; ROBINSON, P. J. Neighbourhoodscale urban forest ecosystem classification. Journal of Environmental Management, v. I63, p. I34-I45, 2015.

STEENBERG, J. W. N.; DUINKER, P. N.; NITOSLAWSKI, S. A. Ecosystem-based management revisited: Updating the concepts for urban forests. Landscape and Urban Planning, v. I86, p. 24-35, 2019. 
VIEIRA, M. G. L.; MORAES, J. L.; BERTONI, J. E. A.; MARTINS, F. R.; ZANDARIN, M. A. Composição florística e estrutura fitossociológica da vegetação arbórea do Parque Estadual de Vassununga, Santa Rita do Passa Quatro (SP). Gleba-II Capetinga Oeste. Revista do Instituto Florestal, v. I, n. I, p. 135-159, 1989.
WU, J. Urban sustainability: an inevitable goal of landscape research. Landscape Ecology, v. 25, p. I-4, 2010.

ZAR, J. H. Biostatistical Analysis. Prentice Hall, 2010.663 p. 